REGULAR ARTICLE

\title{
DETERMINANTS OF INCOME PATTERNS OF TOMATO FARMERS IN GHANA
}

\author{
Daniel AIDOO-MENSAH
}

\author{
Address: \\ Faculty of Applied Sciences, Methodist University College Ghana, P. O. Box 195 Wenchi - Brong Ahafo Region \\ * Corresponding author: danielaidoomensah@gmail.com
}

\begin{abstract}
The study investigated the determinants of income patterns of tomato farmers by means of three income models based on the livelihood approach of linking income and income generating activities. Data for the study was collected from 562 randomly selected tomato farmers from six districts in three regions of Ghana. By employing OLS estimation, the study sought to identify the determinants underlying the respondents' income pattern. The results of the study indicate that gender, wealth, number of years of education experience, number of years of experience in tomato production and farm size were the major socio-economic variables that significantly influenced one's level of income. All the three income models indicate negative but significant relationship between income and the contributions made by secondary earners implying that social and family ties serve as a disincentive to increasing income levels as people take undue advantage of it. Moreover, all three income models study indicate negative but significant relationship between income and household size, an indication that increasing household size has negative consequences on income. The policy implication of this is that as part of agricultural extension activities, education on population issues and its implications for development be passed on to farmers.
\end{abstract}

Keywords: Income Patterns, Tomatoes, Quintile analysis, Diversification, Ghana JEL Codes : Q12, C21, D13

\section{INTRODUCTION}

For most rural households in Sub-Saharan Africa, agriculture is the predominant income generating activity offering strong option for spurring economic growth, overcoming poverty and enhancing food security (Sarah, 2012; Schwarze and Zeller, 2005). In Ghana for instance, agriculture practised primarily on small-scale, is the mainstay of the economy, accounting for $36 \%$ of GDP (2000) and some $60 \%$ of the workforce. Gold and timber are the other main generators of foreign exchange. The industrial sector accounts for some $25 \%$ of GDP, of this manufacturing, which is relatively well-developed and diverse, accounts for $9 \%$ of GDP. The services sector which is equally an important sector accounting for about $32 \%$ of GDP plays second fiddle to the agricultural sector. Therefore, the importance of the agricultural sector and its income levels in a developing country Ghana cannot be overemphasized as it directly influences resource allocation as well as the process and pace of economic diversification particularly in the area of export earnings and cutting down on imports. This is essentially important as the sector will continue to be the dominant sector in spite of rapid growth in the other sectors (Diao, 2010). The main export crop, cocoa, generates $30-40 \%$ of foreign exchange earnings. The cocoa industry in Ghana is not only pivotal to the formal economy of the national but also vital to the informal sector as it employs more than 1.5 million in production and transport.

\section{THE GHANAIAN ECONOMY AND THE PARADOX OF AID AUGMENTATION}

Although Ghana has twice the per capita output of poorer West African countries, it remains heavily dependent on international financial and technical assistance in spite of the fact that it has long been touted as the darling of the international development community for its record of two-decades-plus of "reforms" and, more recently, "macroeconomic stability." Thus, behind this façade of success lies a record of rising but disruptive and inadequate levels of foreign aid, contrasted by a declining trend in the domestic share of development spending. Hence, following the economic crisis which began in the 1970 s and which continued to the 1980s, much of the initial enthusiasm regarding the country's future waned off (Miller, 2009). The Ghanaian economic crisis began against the background of being the first country in SubSaharan Africa to attain independence in 1957 and also reporting the highest Gross National Product on the continent and a relatively stable political system.

Worthy of mentioning is the fact that one of the key outcomes of the economic crisis is the erosion of investorconfidence in the Ghanaian economy, thereby, greatly limiting foreign inflows as the nation is already saddled with heavy debt-service burden. Worsening the situation is the issue of domestic debt which has grown considerably since the mid-1990s, averaging about $31 \%$ per year between 1996 and 2000, and interest payments 
accounting for $19 \%$ of government expenditure in 2000 . Such a debt burden deprives the government of the resources needed to support economic growth. Ghana's external debt has more than quadrupled from US\$1,4bn in 1980 to US\$6,97bn in 2000 (Social Watch, n.d.).

Much of the nation's economic woes have been attributed to the dependence on cocoa as the sole exportable crop which in most instances leave the nation at the mercy of her trading partners in spite of the opportunities for diversification existing outside cocoa production and export (Diao, 2010). Against this background, the clarion call has been made for diversification of the agricultural sector and also to monitor the income situation of agricultural households both from the perspective of monitoring sectoral performance (The Wye Group, 2011) as well as to understand the nature of the earning patterns of the sector. Though, in the Ghanaian context, much has been done in the area of the dominant cash crop - cocoa, in terms of practitioners' income (Gockowski, et al., 2011) and its contribution to the GDP. However, very little is known about the underlining identities and patterns of farm households' income particularly of households or individuals engaged in prominent vegetables such as tomato (Waud, 1983) which offers support for market opportunities and diversification by cutting down on imports as well as improving income levels of farm households (Diao, 2010).

\section{TOMATO PRODUCTION IN GHANA}

Lycopersicon esculentum Mill. commonly referred to as tomato is a vegetable from an annual herbaceous plant. It is widely distributed throughout the tropics and in the temperate regions. In Ghana, it is the most important vegetable and a primary cash crop which serves as an indispensable ingredient in the daily diets of people across all regions as it is used in preparing a wide variety of cuisines such as soups, sauces, and other dishes (Ellis $\boldsymbol{e t}$ al., 1998).

Tomato production is a flourishing farming activity in the savanna and forest-savanna transitional belts of Ghana. It provides good nutritional balance to farm families as well as boosts their income and hence standard of living. In the afore-mentioned ecological belts, the crop is grown on a large scale in such areas as Tono and Vea areas in the Upper East region; Akumadan, Kumawu and Agogo areas in the Ashanti region; Wenchi, Awisa, Yamfo, Abesim, Techiman, Ofuman, Derma and Techimantia areas in the Brong Ahafo region and other areas such as Akim Oda, Nsawam, Suhum, Oyoko in the Eastern region (Adu-Dapaah and Oppong-Konadu, 2002). Its production serves as a lucrative source of employment particularly for the many male youth engaged in its cultivation.

In spite of the role it plays in the financial and nutritional well-being of most farm families in Ghana, production of the crop has not been encouraging over the years (Adu-Dapaah and Oppong-Konadu, 2002). This is due to the fact that the tomato sector in Ghana has failed to reach its potential, in terms of attaining yields comparable to other countries, in terms of the ability to sustain processing plants, and in terms of improving the livelihoods of those households involved in tomato production and the tomato commodity chain (Robinson and Kolavalli, 2010). Ghana, therefore, continues to import several tonnes of tomato and tomato products into the country and the nation has been observed to be second only to Germany as the largest importer of tomato paste, consuming an average of twenty five thousand $(25,000)$ tonnes of tomato paste in a year at a total cost of about $\$ 25$ million dollars (Yeboah, 2011).

In Ghana, the focus of the efforts by various stakeholders in the tomato industry geared towards finding solutions to the myriads of problems associated with tomato production has mostly been looked from the agronomic perspective. However, there is no gainsaying of the fact that these farmers' quest for survival now and into the future in today's ever-changing and challenging environment of economic development hinges not only on agronomic issues but also on their ability to sustain their production activities through their earnings.

This is for the reason that rural households in general, self-finance their economic activities basically from their earnings. Of particular importance is the fact that such earnings are needed to adopt improved technologies in order to maintain or increase their production (Obwona and Ddumba-Ssentamu, 1996; Bautista and Lamberte, 1990). Therefore, a better understanding of the income patterns of tomato farmers will contribute to the formulation of appropriate policies, thereby improving upon local capital formation capacity to enhance tomato production. This is expected to reduce Ghana's importation of tomato products thereby conserving the nation's scarce foreign exchange reserves and also provide employment and development opportunities in the rural communities of the country (Yeboah, 2011).

\section{METHODS AND DATA}

\section{Data}

The empirical research into income dynamics is usually done using either of 2 approaches: macroeconomic (use of aggregate data) and microeconomic which is the same as the use of primary data (Niculescu-Aron, 2012). This study made use of the second approach, that is, the use of primary data.

The primary data used in the study were collected mainly from tomato farmers. The utilization of primary data for the study lies in the fact that analysis of such data can be relied upon to provide accurate information and valuable insights on household income. Furthermore, aggregate data on income issues at the national level has been the subject of many detailed studies with very little attention on primary data which tend to have a wealth of information for policy considerations. Data on respondents' income from tomato production, amount saved per period and farm size were gathered. Demographic and socio-economic factors of importance such as educational background, gender, household size and engagement in non-farm activities were obtained as well. Data were collected through a combination of individual interviews and focus group discussions. 


\section{Sampling Technique}

The total number of respondents for the study was determined using an estimation method based on Bartlett et al., (2001) as Eq. 1:

$n=\frac{Z^{2}(p)(q)}{(E)^{2}}$

Where:

$n$ sample size;

$p$ the proportion of people who access financial services/those who have bank account;

$q$ the proportion of people who do not have to access financial services/those who do not have bank account;

$Z$ number of standard deviation for a chosen confidence interval level;

$E$ the allowable margin of error.

According to GLSS (5) report about $42 \%$ of individuals living in rural areas have access to financial services (savings account) (GSS, 2008). Thus, assuming 95\% confidence level and 5\% margin of error:

$n=\frac{1.96^{2} \times 0.42 \times 0.58}{0.05^{2}}=374$

This implies $n=374$. However, in order to capture the diversity of the selected regions on a more magnified scale, thereby, ensuring fair distribution of the respondents within the selected districts, as well as improving the reliability and validity of the results, the sample was increased by $60 \%$. Thus, the total sample size was approximated to 599; this was proportionally distributed across the districts based on the number of households engaged in agricultural production obtained from the 2010 Population and Housing Census. However, the response rate was $94 \%$, that is, 562 out of the 599 were fit for the analyses.

The sample for the study was selected in three (3) stages; first was the purposive selection of regions Ashanti, Brong Ahafo and Upper East regions. This was followed by the purposive selection of two districts from each region. The selection of the 3 regions and their respective districts took into consideration the volume of tomato production based on official statistics from Ministry of Food and Agriculture (MoFA).

The third stage of the sampling involved random selection of the respondents for the study. This was undertaken with the help of Agricultural Extension Agents (AEAs) in charge of the operational areas in each of the selected districts.

\section{Analytical Framework}

Two main approaches have been extensively used in the development literature to link income and income generating activities. These are the livelihood approach and the asset-activity income approach (Schwarze, 2004). The livelihoods approach places households and their members at the centre of analysis and decision making in investigating activities that play central role in the development and requirement of means of living (Chambers and Conway, 1992; De Haan et al., 2002). Moreover, it stresses the multiplicity of activities that rural households are engaged in, in order to sustain themselves (Schwarze, 2004).

The asset-activity income approach on the other hand focuses on the interventions designed to improve the wellbeing of rural households by expanding asset ownership and access based on the view that it is the household's low asset position that limits its ability to take advantage of opportunities (Winters et al., 2009). It first seeks to identify the important assets in livelihood, their trends over time and space as well as the nature and impacts of shocks and stresses (environmental, economic and social) upon these assets (Morse, McNamara and Acholo, 2009).

The framework for the study takes into consideration the features of the former approach, that is, the livelihood approach. The choice of this approach over the latter is based on the fact that the average household in the tomato business study areas has the main objective of growing tomato not for consumption purpose but purely for commercial reasons. This in a way conforms to conventional econometric analysis of agricultural production, in which the farm is treated as commercial "firm" selling all its output and buying or hiring all the inputs with the single objective of maximizing profit (Upton, 1996). In essence, the cultivation of tomato in the study areas is seen as the main means of acquiring a livelihood or means of economic survival. Thus, the use of labour time and the disposal of the resultant output are determined with reference to market wages and prices of tomatoes (Barnum and Squire, 1979).

Following Barnum and Squire (1979), and Schwarze (2004), the income model is formulated based on the assumption that an average household is engaged in two main income generating activities, that is, an on-farm income generating activity which is centered on cash crop production which is the main source from which the household draws its livelihood and which is designated as $\alpha$; and a non-farm income generating designated as $\beta$. It is also assumed that a household's income generating activities are underlined by such household socioeconomic and demographic characteristics as age of the household head, dependency ratio, wealth, household size, farm size, and number of years of experience in income generating activities.

Thus, the income $\mathrm{y}$ from an income generating activity $i$ which is a function of the household's investment $I$, number of years of experience in income generating activities (or enterprise experience) $S$, price $P$ of output and household characteristics $Z$ is given as Eq. 2.

$y_{i}=y_{i}(I, S, P, Z) \quad i=\alpha, \beta$

Total household income from the two income generating activities is given as Eq. 3 .

$Y=y^{\alpha}+y^{\beta}$

Subject to an investment constraint (Eq. 4).

$I^{\alpha}+I^{\beta} \leq \bar{I}$ 
Given the investment constraint, the optimal allocation of resources between the two income generating activities is given by the first order condition (Eq. 5).

$\frac{d Y}{d I^{\alpha}}=y_{I}^{\alpha}\left(I^{\alpha} ; S^{\alpha} ; P^{\alpha} ; Z^{\alpha}\right)-y_{I}^{\beta}\left(I^{\beta} ; S^{\beta} ; P^{\beta} ; Z^{\beta}\right)=0$

Ensuring a maximum implies that the second order condition must also holds (that is, $y_{I I}^{\alpha} ; y_{I I}^{\beta}$ ). After total differentiation of Equation 4 with respect to $S$ the marginal effect of enterprise experience on investment in on-farm income generating activity is given as Eq. 6 .

$\frac{d I^{\alpha}}{d S}=\frac{y_{I S}^{\beta}-y_{I S}^{\alpha}}{y_{I I}^{\beta}+y_{I I}^{\alpha}}$

Similarly, using the investment constraint, the marginal effect of enterprise experience on investment in non-farm income generating activity is given as Eq. 7 .

$\frac{d I^{\beta}}{d S}=\frac{y_{I S}^{\beta}-y_{I S}^{\alpha}}{y_{I I}^{\beta}+y_{I I}^{\alpha}}$

If the marginal effect of enterprise experience on the net income productivity in investment in on-farm income generating activity $\left(y_{I S}^{\alpha}\right)$ is greater than non-farm income generating activity $\left(y_{I S}^{\beta}\right)$, the numerator become negative. Since the denominator is also negative, an increase in enterprise experience increases investment in on-farm income generating activity. The reverse is obtained if the marginal income effect is higher in non-farm income generating activity than in on-farm income generating activity. Thus, the effects of enterprise experience on net household incomes are given as Eq. 8-9.

$\frac{d y^{\alpha}}{d S}=y_{I}^{\alpha} \cdot \frac{d I^{\alpha}}{d S}+y_{S}^{\alpha}$

$\frac{d y^{\beta}}{d S}=y_{I}^{\beta} \cdot \frac{d I^{\beta}}{d S}+y_{S}^{\beta}$

It is assumed that if the marginal effect of enterprise experience on both activities is positive, the household may increase investments in both activities. This implies that the household has the ability to predict the direction of both enterprises in terms of ability to income, thereby avoiding losses (Awunyo-Vitor, Bakang and Cofie, 2013; Maliwichi, Pfumayaramba and Katlego, 2014). Total income for the two income generating activities is given as Eq. 10 .

$$
Y=\sum y_{i}\left(S, P^{i}, Z^{i}\right) \quad i=\alpha, \beta
$$

\section{Choice of Functional Forms for Income Behaviour}

Three functional forms of the income models were estimated using ordinary least squares (OLS) method. The first functional form termed as Model 1 as shown below expressed actual income as a function of the following independent variables - Gender of respondents (Gen), marital status (Marista), age of respondents (Age), engagement in non-farm activities (Nonfarm), respondent's wealth (Wealth), number of years of education (Yrsedn), number of years of tomato farming experience (Yrstoma), farm size (Farmsize), household size (HH size), relatives (termed as secondary earners) contributing to household income in the form of local or international remittances (Seconenrs) and the value of such remittances (Remit) (Eq. 11).

$$
\begin{aligned}
& Y=\beta_{0}+\beta_{1}(\text { Gen })+\beta_{2}(\text { Marista })+\beta_{3}(\text { Nonfarm })+ \\
& \beta_{4}(\text { Wealth })+\beta_{5}(\text { Yrsedn })+\beta_{6}(\text { Yrstoma })+ \\
& \beta_{7}(\text { Farmsize })+\beta_{8}(\text { H H size })+\beta_{9}(\text { Seconenrs })+ \\
& \beta_{10}(\text { Remit })+\beta_{11}(\text { Age })+\varepsilon_{i}
\end{aligned}
$$

The second functional form (Model 2) as shown below was obtained by transforming the actual income into its natural logarithm components and used as the regressand on the aforementioned variables. The transformation of the regressand was done in order to reduce potential problems of heteroscedasticity and also it served as means of transforming the highly skewed distribution into more approximately normal one. In effect the log-transformation makes the effective relationship non-linear whilst still preserving the linear model (Benoit, 2011) (Eq. 12).

$$
\begin{aligned}
& \text { LnY }=\beta_{0}+\beta_{1}(\text { Gen })+\beta_{2}(\text { Marista })+ \\
& \beta_{3}(\text { Nonfarm })+\beta_{4}(\text { Wealth })+\beta_{5}(\text { Yrsedn })+ \\
& \beta_{6}(\text { Yrstoma })+\beta_{7}(\text { Farmsize })+\beta_{8}(\text { HH size })+ \\
& \beta_{9}(\text { Seconenrs })+\beta_{10}(\text { Remit })+\beta_{11}(\text { Age })+\varepsilon_{i}
\end{aligned}
$$

The third functional form (Model 3) as shown below was obtained by transforming age into its quadratic form, that is, by squaring age. The underlying reason for the quadratic transformation of age lies in the fact that theoretical and empirical research suggests a non-linear relationship between age and income, that is, an inverted U-shaped relationship (Checchi, 2000; AngelesCastro, 2006). Thus, adding the square of the age variable allows a more accurate modelling of the effect of age on income (Eq. 13).

$$
\begin{aligned}
& Y=\beta_{0}+\beta_{1}(\text { Gen })+\beta_{2}(\text { Marista })+\beta_{3}(\text { Nonfarm })+ \\
& \beta_{4}(\text { Wealth })+\beta_{5}(\text { Yrsedn })+\beta_{6}(\text { Yrstoma })+ \\
& \beta_{7}(\text { Farmsize })+\beta_{8}(\text { H H size })+\beta_{9}(\text { Seconenrs })+ \\
& \beta_{10}(\text { Remit })+\beta_{11}(\text { Age })^{2}+\varepsilon_{i}
\end{aligned}
$$

\section{RESULTS AND DISCUSSIONS}

\section{Age}

The respondents for the study were categorized into 3 different age groups as seen on Table 1 . The results of the age distribution of the respondents indicate the mean age to be 39.90 years $(\mathrm{SD}=10.96)$ while the modal age group was the 30-65 years age bracket. This may indicate that there is potential for higher income levels from the tomato sector in Ghana since majority of these respondents are in their middle ages an age bracket in which according to the life cycle hypothesis incomes tend to be high.

\section{Household Size and Dependency Ratio}

A large household size in agricultural production gives 
farmers ample availability of labour pool for farm operations (Amaza et al., 2009). However, a large family size has the unpleasant probability of exerting greater risk of poverty, chronic food insecurity and child malnutrition (Maxwell, 1996). This is especially true when most of the household members are economically dependent on the rest of the household members who are economically active.

Results of household size on Table 1 show that $51.6 \%$ of all the respondents have household size of 4-6 persons. Interestingly all the regions have their highest household size within this household size bracket. Within this household size bracket, the Upper East Region has the highest proportion of $66.5 \%$ followed by Ashanti Region (56.7\%) and Brong Ahafo Region (36.7\%).

Household size is an important economic indicator which brings to the fore the concept of dependency ratio. The dependency ratio relates the population aged 0-14 years and 65 years and above to the working-age population (15-64 years old). The ratio gives a sense of pressure a household or an individual may face in supporting economically dependent ones. This is because a high dependency ratio indicates that the economically active individuals or members of a household and the overall economy face a greater burden to support and provide the social services needed by children and by older persons who are often economically dependent. A dependency ratio of $100.0 \%$ implies one dependent per working person; a figure higher than $100.0 \%$ implies more dependents per worker while a figure lower than 100.0 indicates a lower than one dependent per worker.

As indicated on Table 1, the overall dependency ratio of the respondents is $68.9 \%$. This is however lower than the national age dependency ratio of $73.43 \%$ which was last measured in 2014. An interesting trend is the dependency ratio of the Ashanti Region which is the only one above the $100.0 \%$ threshold. Although for the region as a whole, the dependency ratio $(92.0 \%)$ is under $100.0 \%$, meaning that a person in the working ages has less than one dependent, however, this conceals important variations within the region. It is only in six districts in the region that the ratio is under $100.0 \%$ of which six districts exclude the two districts selected from the region for the study (Modern Ghana, 2016).

\section{Tomato Farm Size}

In most developing economies, the agricultural sector is characterized by smallholder farmers who occupy the majority of land and produce most of the crop and livestock products (Salami, Kamara and Brixiova, 2010). The pattern of tomato production is not different from other agricultural ventures in which farmers make use of small holdings. The underlying reasons for small farm holdings in tomato production in particular have been attributed to the fact that land preparation and other cultural practices are mainly carried out manually.

The average farm size for the pooled sample as indicated on Table 2 is 1.30 hectares (ha) which is below the national average area of production of 2.0 ha per farmer per year for tomato cultivation (Adu-Dapaah and Oppong-Konadu, 2002). Incidentally, the mean farm size of 1.77 ha recorded in the Ashanti Region, which is above that of Brong Ahafo (1.28 ha) and Upper East (0.99 ha), was recorded specifically in the Afrancho-AkomadanNkenkaasu areas of the Offinso North District of the Ashanti region which have been described as the hub of the tomato industry in Ghana.

\section{Quintile Analysis of Respondents' Income from Tomatoes}

By means of quintile analysis, the respondents' total incomes were grouped into 5 equal groups or quintiles, with each group representing $20 \%$ of the population of respondents as indicated on Table 3 . The use of quintile analysis is justified on the grounds that it has been observed to a give a nuanced and clear picture of the measured qualities of a target population (Cook and Manning, 2013).

Table 1 Demographic characteristics of respondents

\begin{tabular}{|c|c|c|c|c|c|c|c|c|}
\hline \multirow[t]{2}{*}{ Variable } & \multicolumn{2}{|c|}{$\begin{array}{l}\text { Ashanti } \\
\text { Region } \\
(\mathrm{N}=134)\end{array}$} & \multicolumn{2}{|c|}{$\begin{array}{l}\text { Brong Ahafo } \\
\text { Region } \\
(\mathrm{N}=237)\end{array}$} & \multicolumn{2}{|c|}{$\begin{array}{l}\text { Upper East } \\
\text { Region } \\
(\mathrm{N}=191)\end{array}$} & \multicolumn{2}{|c|}{$\begin{array}{l}\text { All households } \\
(\mathrm{N}=562)\end{array}$} \\
\hline & $\mathrm{N}$ & $\%$ & $\mathrm{~N}$ & $\%$ & $\mathrm{~N}$ & $\%$ & $\mathrm{~N}$ & $\%$ \\
\hline Age Category & & & & & & & & \\
\hline$<30$ & 13 & 10 & 63 & 27 & 28 & 15 & 104 & 19 \\
\hline $30-65$ & 114 & 85 & 161 & 68 & 162 & 85 & 437 & 78 \\
\hline$>65$ & 7 & 5 & 13 & 5 & 1 & 1 & 21 & 4 \\
\hline Household Size & & & & & & & & \\
\hline$<=3$ & 24 & 17.9 & 74 & 31.2 & 16 & 8.4 & 114 & 20.3 \\
\hline $4-6$ & 76 & 56.7 & 87 & 36.7 & 127 & 66.5 & 290 & 51.6 \\
\hline $7-9$ & 26 & 19.4 & 60 & 25.3 & 42 & 22.0 & 128 & 22.8 \\
\hline$>9$ & 8 & 6.0 & 16 & 6.8 & 6 & 3.1 & 30 & 5.3 \\
\hline Age of dependents & & & & & & & & \\
\hline$<15$ & 276 & 50.4 & 383 & 32.1 & 368 & 38.1 & 1027 & 38.0 \\
\hline $15-65$ & 268 & 48.9 & 763 & 64.0 & 57225 & 59.3 & 1603 & 59.2 \\
\hline$>65$ & 4 & 0.7 & 46 & 3.9 & 965 & 2.6 & 75 & 2.8 \\
\hline Total & 548 & & 1192 & & 368 & & 2705 & \\
\hline Dependency Ratio & & 104.5 & & 56.3 & & 68.6 & & 68.9 \\
\hline
\end{tabular}

Note: The exchange rate at the time of the survey was 558 FCFA (Franc of the African Financial Community) for USD. 
Moreover, this indicator is a measure of inequality in the distribution of income (or consumption) as it reflects the percentage shares of income or consumption accruing to portions of the target population ranked by income or consumption levels (United Nations, 2012).

The first quintile (Quintile 1) represents low income respondents whilst the fifth quintile (Quintile 5) represents the wealthiest respondents with wide array of income levels.

Following Fry, Firestone and Chakraborty (2014), since the distribution of the quintile analysis of the target population (respondents) shows mixed results, it implies that the target population is poor relative to the general population but not the poorest of the poor. By reason of their economic status of being engaged in productive ventures, the respondents though relatively poor may be categorized as being economically active poor. According to the 2010 Population and Housing Census, the economically active poor are predominantly found in the private informal sector and constitute about $86.1 \%$ of the economically active persons. These are people who due to their extremely low and variable incomes coupled with the subsistence nature of their income generating activities, find it difficult to obtain credit from formal financial intermediaries to expand their livelihood activities.

\section{Income Diversification}

Tomato cultivation in the study areas is a major source of income that sustains the livelihood of farmers engaged in its production and their dependants. These farmers more or less depend on yield per unit area of tomato cultivation for their general well-being and economic survival. However, recent declining global terms of trade among other factors present a bleak prospect for the smallholder stakeholders on the agricultural scene to view agricultural production as a sole and fulltime livelihood enterprise (Start, 2017).

Moreover, due to the volatility of tomato prices in recent times, there is a high level of instability inherent in relying on this one commodity for income (Tutu, 2010). Therefore, enterprise diversification, that is, expansion of the range of economic activities outside the farm, can be seen an efficient mechanism to help stabilise income in such an uncertain environment (Ellis, 2000; McNamara and Weiss, 2005).

Following Esrado (2006), the study categorized the respondents into those who have other sources of income apart from tomato cultivation $(\mathrm{N}>1)$ and those who rely solely on tomato cultivation as their source of income generation $(\mathrm{N}=1)$, where $\mathrm{N}$ is the number of income sources. Based on the categorisation, it was found that more than half of the respondents across all the regions (Ashanti Region $=64.9 \%$, Brong Ahafo Region $=63.3 \%$ and Upper East Region=59.7\%) as seen on Table 4 indicated that they are engaged in other income generating activities aside tomato production for their source of income. This is not unexpected given the fact that the tomato sector in Ghana has failed to reach its potential, in terms of attaining yields comparable to other countries, its inability to produce enough to sustain processing plants, and in terms of improving the livelihoods of those households involved in tomato production and the tomato commodity chain (Robinson and Kolavalli, 2010). Thus, tomato farmers are compelled to engage in other income generating activities in order to sustain themselves and also to save towards their future.

An important aspect of income diversification which may be termed as social diversification whereby households/individuals may prefer to depend not only on their own income but remittances from family members was exploited. This was done to further gain insight to why some farmers in the study areas depend solely on tomato cultivation in spite of the huge debts incurred as a result of poor marketing of their produce which in some reported cases led to suicide attempts (Donkoh $\boldsymbol{e t} \boldsymbol{a l}$., 2013).

In order to determine the level of social diversification among the respondents, a cross-tabulation analysis between engagement in other income generation activities and respondents who have adult family members within the working age bracket (15-65 years - that is, working adults), as specified by the Life Cycle Hypothesis and who contribute to their household income, was done.

An interesting outcome of the cross-tabulation (Table $5)$ shows that majority of respondents $(61.6 \%)$ who are engaged in sole tomato cultivation as their source of livelihood are more likely to have working adult family members who contribute to their household income. It can therefore be inferred that since these respondents do not engage in other income activities for their livelihood apart from tomato cultivation, they are more likely to fall on remittances from their working relatives for sustenance in the incidence of tomato failure.

\section{Empirical Analysis of Respondents' Income Patterns Diagnostic Statistics for the models}

Results on the table indicate that the F-statistics for all the 3 models were significant at the $1 \%$ level implying that the predictors as a group were important determinants of the pooled income of the respondents. Of the three models, Models 1 and 3 because of the relatively large $\mathrm{R}^{2}$ values with equally relatively enormous F-statistics indicate that they are better predictors of respondents' income behaviour.

Table 2 Means and standard deviations of respondents' farm sizes (Hectares) by locations

\begin{tabular}{lcccc}
\hline Region & Minimum & Maximum & Mean & Std deviation \\
\hline Ashanti Region $(\mathrm{N}=134)$ & 0.50 & 5.00 & 1.77 & 0.98 \\
Brong Ahafo Region $(\mathrm{N}=237)$ & 0.40 & 7.00 & 1.28 & 0.67 \\
Upper East Region $(\mathrm{N}=191)$ & 0.30 & 6.00 & 0.99 & 0.60 \\
All households $(\mathrm{N}=562)$ & 0.30 & 7.00 & 1.30 & 0.87 \\
\hline
\end{tabular}

Source: Field Survey, 2015 
Table 3 Distribution of Quintile Analysis of Respondents' Total Income

\begin{tabular}{|c|c|c|c|c|c|c|c|c|c|c|c|c|}
\hline \multirow[b]{2}{*}{ Quintile } & \multicolumn{3}{|c|}{$\begin{array}{l}\text { Ashanti Region } \\
(\mathrm{N}=134)\end{array}$} & \multicolumn{3}{|c|}{$\begin{array}{l}\text { Brong Ahafo Region } \\
(\mathrm{N}=237)\end{array}$} & \multicolumn{3}{|c|}{$\begin{array}{l}\text { Upper East Region } \\
(\mathrm{N}=191)\end{array}$} & \multicolumn{3}{|c|}{$\begin{array}{l}\text { All Households } \\
(\mathrm{N}=562)\end{array}$} \\
\hline & Income & $\mathrm{N}$ & $\%$ & Income & $\mathrm{N}$ & $\%$ & Income & $\mathrm{N}$ & $\%$ & Income & $\mathrm{N}$ & $\%$ \\
\hline $1^{\text {st }}$ & 3500 & 31 & 23.1 & 3394.8 & 49 & 20.7 & 2138 & 38 & 19.9 & 2990.8 & 107 & 19.0 \\
\hline $2^{\text {nd }}$ & 4200 & 23 & 17.2 & 3877.2 & 46 & 19.4 & 3040 & 39 & 20.4 & 3750.0 & 120 & 21.4 \\
\hline $3^{\text {rd }}$ & 5160 & 27 & 20.1 & 4889.4 & 48 & 20.2 & 3900 & 39 & 20.4 & 4659.6 & 110 & 19.6 \\
\hline $4^{\text {th }}$ & 5800 & 29 & 21.7 & 5459.6 & 47 & 19.9 & 4759 & 38 & 19.9 & 5420.8 & 113 & 20.1 \\
\hline $5^{\text {th }}$ & 7900 & 24 & 17.9 & 6950.0 & 47 & 19.8 & 6207 & 37 & 19.4 & 7900.0 & 112 & 19.9 \\
\hline Total & & 134 & & & 237 & & & 191 & & & 562 & \\
\hline
\end{tabular}

Source: Field Survey, 2015

Table 4 Distribution of income diversification

\begin{tabular}{|c|c|c|c|c|c|c|c|c|}
\hline \multirow[t]{2}{*}{ Variable } & \multicolumn{2}{|c|}{$\begin{array}{l}\text { Ashanti } \\
\text { Region } \\
(\mathrm{N}=134)\end{array}$} & \multicolumn{2}{|c|}{$\begin{array}{l}\text { Brong Ahafo } \\
\text { Region } \\
(\mathrm{N}=237)\end{array}$} & \multicolumn{2}{|c|}{$\begin{array}{l}\text { Upper East } \\
\text { Region } \\
(\mathrm{N}=191)\end{array}$} & \multicolumn{2}{|c|}{$\begin{array}{l}\text { All households } \\
(\mathrm{N}=562)\end{array}$} \\
\hline & $\mathrm{N}$ & $\%$ & $\mathrm{~N}$ & $\%$ & $\mathrm{~N}$ & $\%$ & $\mathrm{~N}$ & $\%$ \\
\hline \multicolumn{9}{|c|}{ Engagement in other income generation activities } \\
\hline Yes & 87 & 64.9 & 150 & 63.3 & 114 & 59.7 & 351 & 62.5 \\
\hline No & 47 & 35.1 & 87 & 36.7 & 77 & 40.3 & 211 & 37.5 \\
\hline
\end{tabular}

Source: Field Survey, 2015

Table 5 Cross-tabulation between Engagement in other income generation activities and dependence on working adults Engagement in other income generation activities

\begin{tabular}{|c|c|c|c|c|}
\hline & \multicolumn{2}{|c|}{ YES $(N=351)$} & \multicolumn{2}{|c|}{$\mathrm{NO}(\mathrm{N}=211)$} \\
\hline & $\mathrm{N}$ & $\%$ & $\mathrm{~N}$ & $\%$ \\
\hline Working adults contribute to household income & 207 & 59 & 130 & 61.6 \\
\hline Working adults do not contribute to household income & 144 & 41 & 81 & 38.4 \\
\hline TOTAL & 351 & 100 & & 100 \\
\hline
\end{tabular}

Source: Field Survey, 2015

Table 6 Diagnostic Statistics

\begin{tabular}{llll}
\hline MODEL & $\mathrm{R}^{2}$ & F-statistic & $\mathrm{p}$-value \\
\hline Model 1 & 0.618 & $\mathrm{~F}(11,550)=80.906$ & $\mathrm{p}<.001$ \\
Model 2 & 0.595 & $\mathrm{~F}(11,550)=73.480$ & $\mathrm{p}<.001$ \\
Model 3 & 0.617 & $\mathrm{~F}(11,550)=80.680$ & $\mathrm{p}<.001$ \\
\hline
\end{tabular}

Source: Field Survey, 2015

\section{Gender}

From Table 7, all the three models indicate positive but statistically different levels of significance between income and gender. The positive sign is consistent with $a$ priori expectation implying that males are more likely to earn higher incomes in tomato production than females. This confirms the findings of Dunga (2017) who found that female headed households in among low income groups in South Africa have on the average lower incomes compared to male headed households. Similarly, Bertrand et al., (2015) also found that though gender gaps in labour force participation and earnings have both declined in recent times, despite these gains, substantial gender gaps remain both in labour force and in earnings.

In most countries more men work than women and that men get paid more for similar work (IMF, 2015). In other words, higher gaps in labour force participation rates between men and women result in disparity in earnings between the two sexes, thus creating and exacerbating income inequality (Jain-Chandra, 2015). This assertion of higher gaps in labour force participation rates between the two sexes is given credence by the study as about $80 \%$ of the respondents are males. In addition, women have been observed to face several limitations due to genderspecific roles and responsibilities with excessive demand on their time and energy but with comparatively little income to show for all their efforts (Eckman, 1994). Moreover, it is posited that men and women's income levels may differ because of the differences in the degree of economic vulnerability they face resulting in differential access to economic resources which in most cases make women worse off (Chowa, 2006).

\section{Engagement in non-farm activities}

All the three models indicate a significant but negative relationship between engagement in non-farm activities and income. This inverse relationship between income and engagement in non-farm activities is not consistent with $a$ priori expectation. This is because in a sense, the engagement in non-farm activities is deemed as an important component of income diversification which enables practitioners to seek business or employment opportunities other than traditional crop production and livestock rearing (Kim, 2011). Moreover, non-farm incomes are seen as an important form of diversification of incomes and insurance against risks of setback in farm income (Ibekwe et al., 2010). 
However, considering the fact that simple farm tools are employed in the cultivation of tomatoes and the fresh market tomatoes are handpicked, there is the need for high degree of manpower for tomato farm operations. The situation is exacerbated by the ageing population of the tomato farmers (mean age $=39.90$ years) who may not necessarily have enough carrying capacity to undertake the tedious tomato cultural practices as well as carry on additional work outside the farm (Adu-Dapaah and Oppong-Konadu, 2002, Roka, n.d.). It is therefore not surprising that all the models indicate a negative relationship between income and engagement in non-farm activities, implying that such engagement by the respondents whose main income generating activity is tomato cultivation would result in a decrease in income.

\section{Wealth}

From Table 7, it can be seen that across all the models, wealth significantly influenced income at the 5\% level. The positive sign of wealth is consistent with a priori expectation and it is also significantly different from zero at the $10 \%$ level of probability.

In the context of this study, wealth is defined as the stock of respondents' savings and other financial assets, and physical assets less respondents' liabilities. Physical assets are defined to include residential housing, commercial buildings and fixed business investments, fixed farm investments, consumer durable assets and breeding livestock (Kiiza and Pederson, 2002). Financial assets include savings deposits at commercial banks and other financial institutions such as microfinance institutions, savings and loans companies and credit unions, contributions to provident funds and life insurance etc. (Alamgir, 1976; Kiiza and Pederson, 2002). Wealth comes from accumulated savings from past income and the relationship between the two is strongly affected by life cycle effects. That is, the life cycle hypothesis of savings implies a certain relationship between income and wealth (Hatcher, 1998) which is surmised as: older working people have higher assets levels and income than younger people, but retired people tend to have higher wealth and lower income than younger people (Kennickell, 1999). Thus, it can be inferred that wealth can be used to generate income through such means as savings balances which may yield interests and through a flow of dividend payments from shares.

\section{Educational experience}

Model 2 indicates a positive and significant relationship between income and number of years of education and this is consonance with a priori expectation. This is in conformity with the findings of Ibekwe et al., (2010) who also found that education was significant and positively correlated with farm income among rural households in Southeast Nigeria as well as the findings of Weir (1999) among farmers in Ethiopia.

According to Fields (1980), any examination of education and income distribution rests on the premise that education confers economic benefits on its recipients. In Fields' view, two kinds of benefits accrue from education - employment and income benefits. In the case of employment benefits, educational attainment has been found to accelerate access to new and better job opportunities (Card, 1999; Yabiku and Schlabach, 2009). In the case of the latter scenario, education according to Fields (1980) may affect the distribution of income in a variety of ways; particularly by raising the level of income.

\section{Farming experience}

All three models indicate positive and significant relationship between income and the number of years of experience in tomato farming which is consistent with $a$ priori expectation. The result is consistent with those of previous studies such as that of John et al., (2011) who studied the coping strategies of farmers in Borno State (Nigeria) of enhancing their productivity in the face of drought, vis-à-vis, their income, and that of Maliwichi $\boldsymbol{e t}$ al., (2014) among tomato farmers in South Africa.

Table 7 Income Pattern Models

\begin{tabular}{|c|c|c|c|c|c|c|}
\hline Variable & $\begin{array}{l}\text { Model 1 } \\
\mathrm{R}^{2}=0.618 \\
\mathrm{~F}=0.00 \\
\text { Coef. }\end{array}$ & P-value & $\begin{array}{l}\text { Model } 2 \\
\mathrm{R}^{2}=0.595 \\
\mathrm{~F}=0.00 \\
\text { Coef. }\end{array}$ & P-value & $\begin{array}{l}\text { Model } 3 \\
\mathrm{R}^{2}=0.617 \\
\mathrm{~F}=0.00 \\
\text { Coef. }\end{array}$ & P-value \\
\hline Constant & 5958.002 & 0.000 & 8.758 & 0.000 & 5787.983 & 0.000 \\
\hline Gender & 195.180 & $.047 * *$ & .076 & $.011 * *$ & 190.014 & $.053 *$ \\
\hline Marital status & -65.446 & .579 & -.030 & .403 & -88.639 & .447 \\
\hline Engagement in non-farm activities & -1761.014 & $.000 * * *$ & -.497 & $.000 * * *$ & -1759.390 & $.000 * * *$ \\
\hline Wealth & .082 & $.000 * * *$ & $2.221 \mathrm{E}-05$ & $.000 * * *$ & .082 & $.000 * * *$ \\
\hline Educational experience & 9.622 & .187 & .004 & $.076 *$ & 9.899 & .175 \\
\hline Farming experience & 22.540 & $.000 * * *$ & .007 & $.000 * * *$ & 21.967 & $.000 * * *$ \\
\hline Farm size & 159.963 & $.001 * * *$ & .058 & $.000 * * *$ & 159.926 & $.001 * * *$ \\
\hline Household size & -58.689 & $.002 * * *$ & -.016 & $.004 * * *$ & -62.019 & $.001 * * *$ \\
\hline Secondary earners & 170.799 & $.000 * * *$ & .055 & $.000 * * *$ & 172.623 & $.000 * * *$ \\
\hline Contribution by secondary earners & -.283 & $.012 * *$ & $-6.734 \mathrm{E}-05$ & $.046^{* *}$ & -.282 & $.012 * *$ \\
\hline Age & -10.461 & $.031 * *$ & -.004 & $.011 * *$ & & \\
\hline Squared age of respondents & & & & & -0.104 & $0.055^{*}$ \\
\hline
\end{tabular}

Source: Field Survey, $2015 * * *$ significant at 1\%, **significant at 5\%, *significant at 10\% 
This means that an increase in the number of years of tomato farming will increase tomato production, hence, income. This is consistent with the argument that the number of years of farming experience improves farmers' productivity/efficiency since experienced farmers have the ability to predict climatic, soil conditions and pest and disease occurrences on the field (Awunyo-Vitor, Bakang and Cofie, 2013; Maliwichi, Pfumayaramba and Katlego, 2014). It can therefore be inferred the results that all things being equal higher years of farming can effectively help to reduce one's production costs, thereby, making one more efficient to avoid losses resulting in increase in income.

\section{Farm size}

Table 7 indicates that all the three models show a positive and significant relationship between farm size and income. This finding is consistent with a priori expectation and also in line with the findings of Mburu $\boldsymbol{e t}$ al., (2014) whose study on the economic efficiency and farm size among wheat farmers in Kenya indicated that large farms had higher technical efficiency than small scale farms. This invariably implies that large scale farms take advantage of being technical efficient to earn more income than small farms. Dunn and Williams (2010) obtained similar results among farmers in U.S.A.

However, a substantial share of available studies on the assessment of the relationship between farm size and productivity, vis-à-vis, farmers' income particularly in developing countries focuses on an inverse relationship between the two variables - farm size and income (Masterson, 2007; Sial et al, 2012; Mahmood et al., 2014). This finding of inverse relationship between farm size and income gained grounds when Sen $(1962,1966)$ observed an inverse relationship between farm size and output among Indian farmers. On the contrary, in the view of Thapa (2007), recent rapid technology changes and the expansion of commercial farming have changed the perception of efficiency towards small farms, suggesting that the inverse ratio concept diminished when the agricultural sector moved towards modernisation through adoption of more capital intensive technology. This is particularly true of the grains industry where larger farms as a result of economies of scale are able to earn a higher return on capital (Australian Bureau of Statistics, 2012).

Moreover, it has been observed that given the relative abundance of land, most farmers in many developing countries tend to rely on rapid expansion of land as means of increasing income levels (Salami et al., 2010). The situation in the study areas is not much different from what pertains in most developing countries as relatively large acreage of uncultivated land is ready for tomato cultivation particularly in the Ashanti and Brong Ahafo regions in order to increase income flows.

\section{Household size}

All three models indicate negative but significant relationship between income and household size which is consistent with a priori expectation. This is in conformity with the studies done by Anyanmu (2005, 2010, and 2012) which indicated high levels of poverty among large households in Nigeria an indication of low levels of income associated with large household size.

Household size and its negative effect on income has been a matter of great concern not only for the household as unit but for a nation as a whole. This is because pessimism has been expressed about the trend of increasing household sizes and its tendency of a probable explosion of world population which can plunge poor developing countries into further poverty and helpless wretchedness (Arthur, 2005). According to Falk and Sanders (1939), the negative effect of the household size on household income may be more pronounced when there is an increase in the number of household members under 16 years who may not be income earners but have to depend on others. Similarly, the low income associated with large household size may be compounded by an increase in the number of household members above 65 years, that is, those on retirement.

\section{Secondary earners}

Again, all three models show a positive and significant relationship between income and number of secondary earners who contributed to household income. This finding is consistent with a priori expectation. The positive sign indicates that an increase in the number of other family members who contribute to income in the form of local or international would warrant an increase in total household income. This is in consonance with the findings of Dose (2007) who opined that to achieve a secure income for farm households, diversification of livelihoods, as well as diversification of income sources, is considered most important safety net especially in the event of crop failure.

\section{Contribution by secondary earners}

All the three models indicate negative but significant relationship between income and the contributions made by secondary earners. This is however not consistent with a priori expectation as it is assumed that all things being equal, addition of the contributions in the form of remittances made by secondary earners to household income will help boost income levels. The negative sign may be best explained by the fact that strong family and social interdependence seems to serve as a buffer to low income levels (Bendig et al., 2009). In other words, the social and family ties serve as a disincentive to increasing income levels as people take undue advantage of it and may even depend on such assistance to save towards their future. Thus, it can be argued that remittances create a behavioural change bordering on dependency syndrome among recipients which makes them overly dependent on external assistance.

\section{Age and age squared}

Though Models 1 and 2 indicate that age is significant, their coefficients signify a negative relationship between age and income which is contrary to a priori expectation. This is because in general all things being, income increases with age since workers become more experienced with passage of time. However, as workers increase in age, income begins to increase but at a decreasing rate (Saint-Pierre, 1996) as aging negatively 
affects one's health, thereby, reducing one's ability to work as before. At some point in time in the aging process, income does not grow (reaches an optimal level) but rather starts to fall (point of retirement) as income earners reach decrepitude. This gives an inverted U-shaped relationship between income and age as suggested by the life cycle hypothesis, thereby, negatively affecting their savings as dissaving may set in.

The negative sign, thus, implies that the respondents might have already reached their prime, that is, the tomato farmers are becoming less productive as they age (Weir, 1999). This assertion concurs with the study by Kodom (2013) which found that among households in Ga-East Municipality the maximum age limit at which people held much savings ( a proxy for higher levels of income) was 36 years and the highest savings was recorded at 31 years. Beyond these age limits, the average savings declined possibly due to decline in income as well. Generally, it is expected that saving (by implication income) by adult population (especially above 30 years) would be diminishing with as they grow towards and beyond retirement age (Kibet $\boldsymbol{e t}$ al., 2009). The results of the age distribution of the respondents indicate the mean age to be 39.90 years $(\mathrm{SD}=10.96)$ while the modal age group was the 30-65 years age bracket. It can therefore be concluded that the findings of inverse relationship between income and age essentially signifies that the respondents are already in their prime. Thus, squaring age as indicated by Model 3, allows the modeling of the effect of different ages on income which in actual fact is non-linear and negative, which is significant and with the appropriate negative sign as indicated by Model 3 .

\section{CONCLUSIONS \\ RECOMMENDATION}

AND

POLICY

The study focused on four essential agricultural sources of income, including food crop surplus sale, vegetable sale, horticultural sale, and cattle sale. Multivariate probit regression was used to estimate the possible correlation between different dependent variables. However, the results show that about $77 \%$ of sampled farmers sold food crops surplus, $40 \%$ participated in horticulture production sale, and $32 \%$ of sampled farmers participated in the sale of vegetable production market and the sale of cattle. The results indicate that there are substantial complementarity and substitutability among sources of income. Correlation matrix analysis showed a positive and negative correlation which was not statistically significant among different sources of income generation. Econometric results show that age of family head, family size, dependency ratio, land ownership, education level, cash crop income, offfarm income, access to credit, high cost of agricultural inputs, infrastructure and price of agricultural commodities positively and significantly influenced the likelihood of farmer participation in vegetable and horticultural production and marketing. The results also indicate that extension services, education level, and infrastructure negatively influenced farming family participation in vegetable and horticulture production and marketing. The major recommendation is that, smallholder farmers in Southern-Mali should consider, vegetable and horticulture production for commercial purposes not for subsistence agriculture. Based on findings, subsidized agricultural inputs will enhance smallholder livelihood improvement through increased agricultural productivity and participation in the market outlet.

\section{REFERENCES}

ADU-DAPAAH, H. K. and OPPONG-KONADU, E. Y. (2002). Tomato production in four major tomato-growing districts in Ghana: Farming practices and production constraints, Ghana Journal of Agricultural Science, 35, 11-22. DOI: http://dx.doi.org/10.4314/gjas.v35i1.1840

ALAMGIR, M. (1976). Rural savings and investment in developing countries: Some conceptual and empirical issues, The Bangladesh Development Studies, 4(1), 1-48. AMAZA, P., ABDOULAYE, T., KWAGHE, P. and TEGBARU, A. (2009). Changes in household food security and poverty status in PROSAB area of Southern Borno State, Nigeria, International Institute of Tropical Agriculture.

ANGELES-CASTRO, G. (2006). The relationship between economic growth and inequality: evidence from the age of market liberalism. Web Source: Retrieved December 15 ,

https://www.econstor.eu/handle/10419/19830

2015

ANYANWU, J. C. (2005). Rural poverty in Nigeria: profile, determinants and exit paths, African Development Review, 17, (3), 435-460. DOI: https://doi.org/10.1111/j.1017-6772.2006.00123.x

ANYANWU, J. C. (2010). Poverty in Nigeria: a gendered analysis, African Statistical Journal, 11, 38-61.

ANYANWU, J. C. (2012). Accounting for poverty in Nigeria: illustration with survey data from Nigeria, African Development Bank Working Paper, No. 149.

ARTHUR, J, L. (2005). Family size and its socioeconomic implications in the Sunyani Municipality of the Brong Ahafo Region of Ghana, West Africa (MSc. Dissertation) submitted to University of Cape Coast AUSTRALIAN BUREAU OF STATISTICS (2012). Crops and pastures data Series. Web Source: Retrieved August 15, 2016 from http://www.landcommodities.com/the-importance-offarm-size-and-economies-of-scale/

AWUNYO-VITOR, D., BAKANG, J. and COFIE, S. (2013). Estimation of farm level technical efficiency of small-scale cowpea production in Ghana, AmericanEurasian J. Agric. and Environ. Sci., 13 (8), 1080-1087. DOI: https://www.idosi.org/aejaes/jaes13(8)13/9.pdf

BARNUM, H and SQUIRE, L. (1979). An econometric application of the theory of the farm-household, Journal of Development Economics, 6, 79-102. DOI: https://doi.org/10.1016/0304-3878(79)90037-3

BAUTISTA, R. M. and LAMBERTE, B. L. (1990). Comparative saving behavior of rural and urban households in the Philippines, Philippine Institute for Development Studies (PIDS) Working Paper, No. 90-15. BENDIG, M., GIESBERT, L. and STEINER, S. (2009). Savings, credit and insurance: household demand for formal financial services in rural Ghana, GIGA Working 
Paper No. $\quad 94$.

https://dx.doi.org/10.2139/ssrn.1341550

BENOIT, K. (2011). Linear Regression Models with Logarithmic Transformations, London School of Economics

BERTRAND, M., KAMENICA, E. and PAN, J. (2015). Gender identity and relative income within households, The Quarterly Journal of Economics, Volume 130, Issue 2, 1 May 2015, Pages 571-614, DOI: https://doi.org/10.1093/qje/qjv001

CARD, D. (1999). The causal effect of education on earnings in Handbook of Labor Economics,3. Ashenfelter, O.and Card, D. (Eds.). Elsevier Science. DOI: https://doi.org/10.1016/S1573-4463(99)03011-4

CHAMBERS, R. and CONWAY, G. R. (1992). Sustainable rural livelihood: Practical concepts for the $21^{\text {st }}$ century, IDS Discussion Paper 296

CHECCHI, D. (2000). Does educational achievement help to explain income inequality? UNU World Institute for Development Economics Research (UNU/WIDER) Working Papers no. 208

CHOWA, G. A. N. (2006). Savings performance among rural households in Sub-Saharan Africa: The effect of gender, International Consortium for Social Development. COOK, B. and MANNING, W. G. (2013). Thinking beyond the mean: a practical guide for using quantile regression methods for health services research, Shanghai Arch Psychiatry, 25(2), 130-135. DOI: https://www.ncbi.nlm.nih.gov/pmc/articles/PMC4054530 DE HAAN, A., DRINKWATER, M., RAKODI, C. and WESTLEY, K. (2002). Methods for understanding urban poverty and livelihoods in Sustainable Urban Livelihoods and Marketplace Social Capital: Crisis and Strategy in Petty Trade, Urban Studies, 42, 1301-1320

DIAO, X. (2010). Economic importance of agriculture for sustainable development and poverty reduction: findings from a case study of Ghana, Working Party on Agricultural Policy and Markets, 40.

DONKOH, S. A., TACHEGA, M., and AMOWINE, N. (2013). Estimating technical efficiency of tomato production in northern Ghana, American Journal of Experimental Agriculture 3(1), 56-75. DOI: https://doi.org/10.9734/AJEA/2013/1447

DOSE, H. (2007). Securing household income among small-scale farmers in Kakamega District: Possibilities and limitations of diversification, GIGA Working Paper Series DOI: https://dx.doi.org/10.2139/ssrn.978168

DUNGA, S. H. (2017). A gender and marital status analysis of household income in a low-income township, Studia Universitatis Babeș-Bolyai Oeconomica, 62 (1), 20-30. DOI: https://doi.org/10.1515/subboec-2017-0002 DUNN, J. W. and WILLIAMS, J. R. (2010). Farm characteristics that influence net farm income variability and losses, Paper presented at Western Agricultural Economics Association Annual Meeting, Vancouver, British Columbia.

ECKMAN, K. (1994). Rural households and sustainability: integrating environmental and gender concerns into home economics curricula, Working Document, Food and Agriculture Organization of The United Nations, Rome.
ELLIS, F. (2000). Rural livelihoods and diversity in developing countries. Oxford: Oxford

ELLIS, W.O., AGBEMATLE, R., OLDHAM, J. H. and NSIAH, K. (1998). Tomato paste production at the rural small-scale level in Proceedings of a Workshop to Evaluate Outputs and Identify Further Vegetable Research Priorities in the Brong Ahafo Region of Ghana. 56-71.

http://dspace.knust.edu.gh/handle/123456789/2618

ESRADO, L. (2006). Income diversification in Zimbabwe: welfare implications from urban and rural areas, World Bank Policy Research Working Paper 3964. http://hdl.handle.net/10986/8389

FALK, I. S. and SANDERS, B. S. (1939). The economic status of urban families and children, Social Security Bulletin, 2(5)

FIELDS, G. S. (1980). Education and income distribution in developing countries: A review of the literature in $\mathrm{T}$. King (Ed.), Education and income: A background study for world development (231-315). Washington, DC: The World Bank.

FRY, K., FIRESTONE, R. and CHAKRABORTY, N.M. (2014). Measuring equity with nationally representative wealth quintiles. Washington, DC: PSI.

GOCKOWSKI, J., AFARI-SEFA, V., SARPONG, D.B., OSEI-ASARE, Y.B. and DZIWORNU, A.K. (2011). Increasing Income of Ghanaian Cocoa Farmers: Is introduction of fine flavour cocoa a viable alternative, Quarterly Journal of International Agriculture 50 (2011), No. 2:

175-200.

https://ageconsearch.umn.edu/bitstream/155531/2/4_Goc kowski.pdf

HATCHER, C. B. (1998). Regarding the relationship between income and wealth in retirement, Financial Counseling and Planning, 9, 2

IBEKWE, U.C, EZE, C.C., ONYEMAUWA, C.S., HENRI-UKOHA, A., KORIE, O.C. and NWAIWU, I.U. (2010). Determinants of farm and off-farm income among farm households in South East Nigeria, Academia Arena, 2 (10), 58-61

IMF, (2015). Gender and income inequality, Web Source: Retrieved July $12, \quad 2016$ from https://www.imf.org/external/pubs/ft/sdn/2015/sdn1520_i $n f o . p d f$

JAIN-CHANDRA, S. (2015). Why gender and income inequality are linked, Web Source: Retrieved June 20, 2015 from

https://www.weforum.org/agenda/2015/10/why-genderand-income-inequality-are-linked/

JOHN, N., IHEANACHO, A. C. and IREFIN, D. (2011). Effects of socio-economic characteristics on the selection of coping strategies against drought in Borno State, Nigeria, Lincoln University Journal of Science, 2 (1).

KENNICKELL, A. B. (1999). Using income data to predict wealth. In memory of Daniel B. Radner. 23 pp.

KIBET, L. K., MUTAI, B. K., OUMA, D. E., OUMA, S. A., and OWUOR, G. (2009). Determinants of household saving: case study of smallholder farmers, entrepreneurs and teachers in rural areas of Kenya, Journal of Development and Agricultural Economics, 1(7), 137-143. KIM, H. (2011). Livelihood diversification in rural Uganda: Its pattern and contribution to income 
generation with a focus on the role of social network, (Unpublished MSc thesis). University of London

KIIZA, B. and PEDERSON, G. (2002). Household financial savings mobilisation: Empirical evidence from Uganda, Journal of African Economies, 10(4), 390-409. DOI: https://doi.org/10.1093/jae/10.4.390

KODOM, M. (2013). Savings habit and use of savings among households in Ga-East Municipality, (Unpublished master thesis). University of Ghana, Legon, Accra.

MCNAMARA, K. T. and WEISS, C. (2005). Farm household income and on- and off-farm diversification, Journal of Agriculture and Applied Economics, 37(1), 3748.

MAHMOOD, H. Z., QASIM, M., KHAN, M. and HUSNAIN, M. I. U. (2014). Re-examining the inverse relationship between farm size and productivity in Pakistan, The Journal of Animal and Plant Sciences, 24(5): 2014, 1537-1546. DOI: https://doi.org/10.1108/CAER-09-2011-0108

MALIWICHI, L. L., PFUMAYARAMBA, T.K. and KATLEGO, T. (2014). An analysis of constraints that affect smallholder farmers in the production of tomatoes in Ga-Mphahlele, LepelleNkumbi Municipality, Limpopo Province, South Africa, Journal of Human Ecology, 47(3), 269-274.

DOI: https://doi.org/10.1080/09709274.2014.11906761

MASTERSON, T. (2007). Productivity, Technical Efficiency, and Farm Size in Paraguayan Agriculture, Working Paper No. 490.The Levy Economics Institute MAXWELL, D. G. (1996). Measuring food security the frequency and severity of escaping strategies, Food Policy, 21(3), 292-300. DOI: https://doi.org/10.1016/0306-9192(96)00005-X

MBURU, S., ACKELLO-OGUTU, C. and MULWA, R. (2014). Analysis of economic efficiency and farm size: a case study of wheat farmers in Nakuru District, Kenya, Economics Research International. DOI: http://dx.doi.org/10.1155/2014/802706

MILLER, B. P. (2009). Women and science in development: A longitudinal analysis of gender, networks, and information technology in Ghana, Kenya, and India, (Unpublished $\mathrm{PhD}$ thesis). Louisiana State University and Agricultural and Mechanical College.

MODERN GHANA. (2016). About regions of Ghana. Web Source: Retrieved from the website of Modern Ghana,

https://www.modernghana.com/ghanahome/regions/asha nti.asp?menu $\% 20 \mathrm{id} \% 20=6$

MORSE, S., MCNAMARA, N. and ACHOLO, M. (2009). Sustainable livelihood approach: A critical analysis of theory and practice, University of Reading, Geographical Paper No. 189

OBWONA, M. B. and SSENTAMU, J. D. (1996). Nature and determinants of domestic savings in Uganda, Economic Policy Research Centre, Research Series No. 2. PPMED (1997). Report on vegetable production in Ghana, 1970-1996, Accra: Statistics Division of the Policy Planning, Monitoring, and Evaluation Division of the Ministry of Agriculture. 25 pp.

ROBINSON, E. J. Z. and KOLAVALLI, S. L. (2010). The case of tomato in Ghana: Productivity, GSSP Working Paper No. 19
ROKA, F. M. (n.d.). Immigration reform: implications for farmers, farm workers, and communities labor issues confronting Florida tomato and orange growers, Web Source: Retrieved September 20, 2016 from https://migrationfiles.ucdavis.edu/uploads/cf/files/2010may/roka-paper-labor-issues-confronting-florida.pdf

SAINT-PIERRE, Y. (1996). Doing earnings rise until retirement? Perspectives on Labour and Income. Vol. 8, No. 2. Summer.

SALAMI, A., KAMARA, A. B. and BRIXIOVA, Z. (2010). Smallholder agriculture in East Africa: trends, constraints and opportunities, Working Papers Series No. 105, African Development Bank.

SARAH, A. (2012). Determinants of Rural Household Income Diversification in Senegal and Kenya.

SCHWARZE, S. (2004). Determinants of income generating activities of rural households: A quantitative study in the vicinity of the Lore-Lindu National Park in Central Sulawesi/Indonesia, (Unpublished doctoral thesis). Georg-August-University of Göttingen. http://hdl.handle.net/11858/00-1735-0000-0006-AB44-4

SCHWARZE, S. and ZELLER, M. (2005). Income diversification of rural households in Central Sulawesi, Indonesia, Quarterly Journal of International Agriculture 44 (2005), No. 1: 61-73

SEN, A. K. (1962). An Aspect of Indian Agriculture, The Economic Weekly.

SEN, A. K. (1966). Peasants and dualism with or without surplus labor, The Journal of Political Economy, 74, 425450

SIAL, M. H., IQBAL, S. and SHEIKH, A. D. (2012). Farm size-productivity relationship: Recent evidence from Central Punjab, Pakistan Economic and Social Review, 50(2), 139-162. https://www.jstor.org/stable/43855778

SOCIAL WATCH (n.d.). Growing dependence on inadequate foreign aid, Web Source: Retrieved December, 20, 2015 from http://www.socialwatch.org/node/11001 START, D. (2017). Rural diversification: what hope for the poor? Web Source: Retrieved from the website of Overseas Development Institute. https://www.odi.org/resources/docs/5900.pdf

THAPA, S. (2007). The relationship between farm size and productivity: Empirical evidence from the Nepalese mid-hills, Contributed paper prepared for presentation at the 106th seminar of the EAAE. Pro-poor development in low income countries: Food, agriculture, trade, and environment 25-27 October 2007 - Montpellier, France

THE WYE GROUP HANDBOOK, (2011). Report of the Wye Group on statistics on rural development and agricultural household income, Report to The United Nations Statistical Commission

TUTU, A. P. (2010). An empirical investigation of the costs and benefits from moving up the supply chain: The case of Ghana cocoa, (An unpublished dissertation). Ashesi University College

UNITED NATIONS. (2012). Share of poorest quintile in national consumption, MDG Wiki Handbook.

UPTON, M. (1996). The economics of tropical farming systems, Wye Studies in Agricultural and Rural Development, Cambridge University Press, Cambridge, UK. DOI: https://doi.org/10.1017/CBO9781139172868 
WAUD, R.N. (1983). Economics (2 ${ }^{\text {nd }}$ edition), New York: Harper and Row Publishers.

WEIR, S. (1999). The effects of education on farmer productivity in rural Ethiopia,Web Source: Retrieved July 18 ,

2017

http://citeseerx.ist.psu.edu/viewdoc/download?doi=10.1. $1.137 .7080 \& \mathrm{rep}=\mathrm{rep} 1 \&$ type $=$ pdf

WINTERS, P., DAVIS, B., CARLETTO, G., COVARRUBIAS, K., QUINONES, E. J., ZEZZA, A., AZZARRI, C. and STAMOULIS, K. (2009). Assets, activities and rural income generation: Evidence from a multicounty analysis, World Development, 37 (9), 14351452.

https://doi.org/10.1016/j.worlddev.2009.01.010
YABIKU, S. T. and SCHLABACH, S. (2009). Social change and the relationships between education and employment, Popul Res Policy Rev., 28(4), 533-549. DOI: https://10.1007/s11113-008-9117-2

YEBOAH, A. K. (2011). A survey on postharvest handling, preservation and processing methods of tomato (Solanum lycopersicum) in the Dormaa and Tano South Districts of the Brong Ahafo Region of Ghana, (Unpublished MSc. thesis). Kwame Nkrumah University of Science and Technology. 